\title{
A Study on Electrical Resistivity Behaviors of PAN-based Carbon Nanofiber Webs
}

\author{
Soo-Jin Park ${ }^{1, \uparrow}$, Se-Hyuk $\mathrm{Im}^{2}$, John M. Rhee ${ }^{2}$ and Young-Seak Lee \\ ${ }^{1}$ Dept. of Chemistry, Inha Univ., 253 Nam-gu, Incheon 402-751, Korea \\ ${ }^{2}$ Dept. of Advanced Organic Materials Engineering, Chonbuk National Univ., 664-14 Dukjin-gu, Jeonju 561-756, Korea \\ ${ }^{3}$ Dept. of Fine Chemical Engineering and Chemistry, Chungnam National Univ., 220 Kung-dong, Yuseong, Daejeon 305-764, Korea \\ ^e-mail: sipark@inha.ac.kr \\ (Received February 14, 2007; Accepted March 15, 2007)
}

\begin{abstract}
The influences of various carbonization temperatures on electrical resistivity and morphologies of polyacrylonitrile (PAN)-based nanofiber webs were studied. The diameter size distribution and morphologies of the nanofiber webs were observed by a scanning electron microscope. The electrical resistivity behaviors of the webs were evaluated by a volume resistivity tester. From the results, the volume resistivity of the carbon webs was ranged from $5.1 \times 10^{-1} \Omega \cdot \mathrm{cm}$ to $3.0 \times 10^{-2} \Omega \cdot \mathrm{cm}$, and the average diameter of the fiber webs was varied in the range of 310 to $160 \mathrm{~nm}$ with increasing the carbonization temperature. These results could be explained that the graphitic region of carbon webs was formed after carbonization at high temperatures. And the amorphous structure of polymeric fiber webs was significantly changed to the graphitic crystalline, resulting in shrinking the size of fiber diameters.
\end{abstract}

Keywords : Polyacrylonitrile, Electrical resistivity, Morphologies, Carbonization temperature

\section{1. 서 론}

탄소섬유는 탄소원소의 질량함유율이 $90 \%$ 이상으로 이루어 진 섬유장의 탄소재료를 일컬으며, 복합구조재, 우주항공, 정 보통신 분야에 널리 사용되고 있다. 이러한 탄소섬유의 발전 은 최근 여러 산업분야에서 나노기술의 급격한 부각과 함께 나노섬유 제조기술에 대한 연구가 활발히 이루어져 수백 나노 미터 규모의 직경을 갖는 나노섬유 제조기술에 밑거름이 되었 다[1].

나노섬유를 제조하는 방법에는 현재 각기 다른 반응성기를 갖고 있는 블록단위의 모노머를 반응시키는 블록 공중합체 과 정에서 각성분의 상분리 현상을 이용하여 제조하는 방법, 나 노크기의 직경을 지닌 나노 반응기에서 고분자의 중합과 동시 에 배향되어 얻는 방법, 서로 상용성이 없고 탄화 정도가 크 게 다른 두 고분자의 복합섬유를 제조한 후 탄화시켜 얻는 방 법, 그리고 고분자 용액 또는 용융체의 전기방사법을 이용하 여 제조하는 방법이 있다[2-4].

전기방사는 1934년 Formhals에 의해 고분자 섬유의 제조 가 능성이 제시되었으며[5-8] 고분자 용액에 높은 전압을 인가하 여 발생시킨 정전기적 반발력과 전기장을 이용하여 나노크기 의 직경을 가진 섬유를 제조하는 직접적인 방법이다[9-11]. 전 기방사는 제조공정이 간단하고, 간단한 장비를 이용하여 제조 할 수 있어 다양한 제품기술에 응용할 수 있고, 작은 기공크 기와 높은 비표면적을 가진 3차원적인 웹형태로 필터재나 전
극재료의 높은 응용성을 고려할 때 전기방사법이 나노섬유 제 조에 가장 유력한 기술로 평가되고 있다 $[2-5,12,13]$.

전기방사는 고분자 용액이나 용융물에 가해진 전기장을 이 용하여 수백 $\mathrm{nm}$ 크기의 섬유로 이루어진 부직포 웹을 얻는 공 정이다. 종래에 섬유방사 기술은 고분자 용융물이나 고분자 용 액에 기계적 힘을 가하여 방사노즐로 압출시켜 섬유화 시키는 반면, 전기방사는 정전기적 힘을 이용하고 있다. 전기방사에서 전압이 인가되기 전에 실린지에 넣어진 고분자 용액이나 용융 물은 표면장력으로 인해 방사노즐(capillary tube)의 끝에 매달 려 미세방울 형태로 있다가 수십 $\mathrm{kV}$ 의 전압이 가해지면 전하 가 액체표면에 유도되고 유도된 전하의 상호반발력이 액체의 표면장력과 반대방향으로 형성된다[14-17]. 이러한 전기적 반 발력에 의해 방사노즐 끝에 매달려 있는 미세방울은 표면장력 과 반대방향으로 일그러지기 시작하여 테일러콘(Taylor cone) 을 형성하며 용액의 표면장력보다 전기적 반발력이 커지게 되 면 전하를 띤 고분자 용액 분사체(jet)가 방사노즐에서 분사된 다[18, 19].

분사체는 집속체에 수집되기 전에 그 유체의 불안정성은 증 가하며, 안정화를 취하기 위하여 고분자 전하를 띤 고체 섬유 형태로 집속체에 집속하게 된다. 고분자 용액 분사체는 방사 되면서 용매는 휘발되고 나노크기의 직경을 갖는 섬유가 집속 체에 3차원의 네트워크 구조로 적층되며, 부직포 형태의 나노 섬유 웹(web)을 형성하게 된다[2, 20].

섬유의 공정인자로는 점도, 용액의 표면장력, 방사거리, 인 
가전압 등이 있으며, 이러한 공정인자를 제어하여 다양한 크 기의 섬유웹 제조가 가능하다. 전기방사는 매우 광범위한 고 분자 소재에 적용 가능하며 초박막 및 초경량 소재의 제조가 가능하다. 특히 적은 양의 고분자 용액으로도 방사가 가능하 고, 방사공정의 어려움으로 제조하기 어려웠던 소재도 방사가 가능하다. 제조된 웹은 섬유의 직경이 작아 높은 표면적 크기 와 유연성이 있어 압착가공이 용이하며 높은 공극률을 가지고 있고 복합성분의 나노섬유 연사(nanofiber yarn) 제조가 가능 하여 멤브레인, 의료재, 전극소재, 인공혈관, 나노복합재료 등 으로 무한한 가능성이 기대되며 복합재료의 강화재로 사용될 경우 물리적 강도를 향상시키기 때문에 고부가가치 산업의 첨 단기술로 자리매김하고 있다 $[21,22]$ 또한, 활성화할 경우 비 표면적이 크고 기공의 깊이가 낮아 높은 충 - 방전 속도에서 도 높은 비용량을 나타낼 수 있어 전극제조의 응용 가능성이 높고 접합체가 필요치 않아 비표면적과 세공을 증가시켜 전도 성 향상을 기대할 수 있어 전극재료에 응용이 가능하다[23].

본 연구에서는 탄소섬유 전구체인 polyacrylonitrile(PAN)을 $N, N$-Dimethylformamide(DMF)에 용해시킨 후 전기방사를 이 용하여 나노섬유 웹을 제조하였으며, 안정화 및 탄화온도가 탄 소 섬유웹의 직경에 미치는 영향과 전기적 특성에 미치는 영 향에 관해서 고찰하고자 하였다.

\section{2. 실 험}

\section{1. 재료 및 방사용액 제조}

본 연구에서 폴리머로 사용한 PAN(polyacrylonitrile)과 용매
PAN<smiles>CC(C)(C)CC(C#N)C(C)(C)C</smiles>

DMF

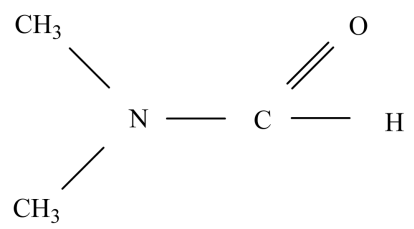

Fig. 1. Chemical structures of PAN and DMF.

로 사용한 $\mathrm{DMF}(N, N$-dimethylformamide)는 Aldrich(주)에서 제 공받았으며 Fig. 1에 PAN과 DMF의 화학구조를 나타내었으 며, Table 1에 각각의 물성을 나타내었다.

폴리머인 PAN을 DMF 용매에 첨가하여 $10 \mathrm{wt} \%$ 로 방사 용 액을 제조하였으며 용액을 균일한 상태에서 사용하기 위하여 제조한 용액을 hot plate와 교반용 자석을 이용하여 $50^{\circ} \mathrm{C}$ 에서 12 시간 가열하여 용해시켰다.

\section{2. 전기방사}

고전압 직류발생 장치(주)ConverTech, SHV-120 Series 120 $\mathrm{W})$ 는 전압 범위가 $1 \sim 36 \mathrm{kV}$ 이며 전압 크기의 조정이 가능한 것을 사용하여 전기방사를 행하였으며, 섬유 웹을 제조하기 위 해서 방사용액을 $5 \mathrm{ml}$ 의 폴리프로필렌 실린지에 넣은 후 팁 내경 및 외경이 각각 $0.42 \mathrm{~mm}, 0.72 \mathrm{~mm}$ 인 $\mathrm{MN}-22 \mathrm{G}$ 니들에 양 전하를 띤 전압선을 연결 후 집속체에는 음전하를 접촉시켜 고전압 발생기와 실린지 펌프를 이용하여 전기방사하였다. 또 한, 전기장은 주위에 있는 물질에 많은 영향을 받는다고 알려 져 있어 실린지 주위 $50 \mathrm{~cm}$ 내에는 집속체 이외에는 다른 장 치를 설치하지 않았다. 전극간 거리(tip-to-collector distance,

Table 1. Physical properties of polymer and solvent

\begin{tabular}{ccccc}
\hline Acronym & Formula & Formula weight & Melting point $\left({ }^{\circ} \mathrm{C}\right)$ & Density $(\mathrm{g} / \mathrm{mL})$ \\
\hline PAN & $\left(\mathrm{C}_{3} \mathrm{H}_{3} \mathrm{~N}\right)_{\mathrm{n}}$ & 86,200 & 317 & 1.18 \\
DMF & $\left(\mathrm{CH}_{3}\right)_{2} \mathrm{NCH}_{2} \mathrm{CH}_{2} \mathrm{NH}_{2}$ & 73.1 & -61 & 0.94 \\
\hline
\end{tabular}

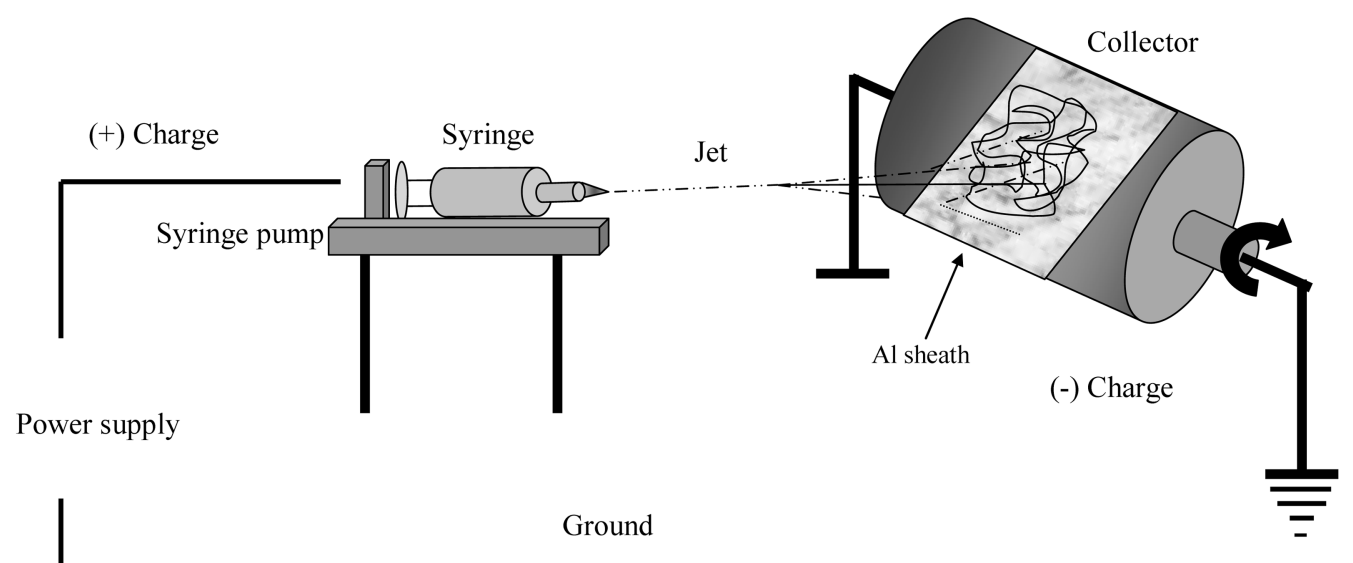

Fig. 2. Schematic diagram of the electrospinning method. 


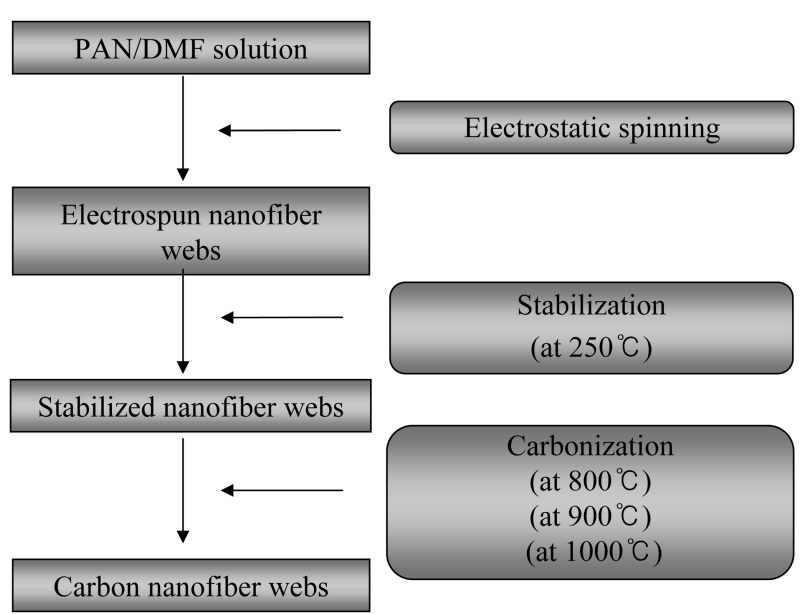

Fig. 3. Preparation process of the samples.

$\mathrm{TCD}$ )는 $10 \mathrm{~cm}$ 로 하였으며, 방사용액의 토출속도는 $0.035 \mathrm{ml} /$ $\min$ 으로 고정하였으며 전압은 계산식을 이용하여 산출하였다 [24]. 본 실험에서 이용한 전기방사 장치는 실험실 자체적으로 제작하였으며, Fig. 2에 실험에 사용한 전기방사 장치의 모식 도를 나타내었다.

\section{3. 안정화 및 탄소화}

전기방사한 PAN/DMF 나노섬유 웹을 가로, 세로 $10 \times 10 \mathrm{~cm}$ 로 절단하여 튜브형 furnace(월드가스테크(주), Korea)를 사용하 여 공기를 $100 \mathrm{ml} / \mathrm{min}$ 의 양으로 공급하면서 $30^{\circ} \mathrm{C}$ 에서 $250^{\circ} \mathrm{C}$ 까지 승온속도 $1^{\circ} \mathrm{C} / \mathrm{min}$ 로 가열하여 주었으며, $250^{\circ} \mathrm{C}$ 에서 1 시 간을 유지시켜 안정화시켰다 $[25,26]$.

탄소화 공정은 안정화 공정을 거친 나노섬유 웹을 튜브형 furnace를 사용하여 $99.99 \%$ 의 고순도 질소가스를 $100 \mathrm{ml} / \mathrm{min}$ 의 양으로 공급하면서 $30^{\circ} \mathrm{C}$ 에서 $250^{\circ} \mathrm{C}$ 까지 승온속도 $1{ }^{\circ} \mathrm{C} / \mathrm{min}$ 로 가열하여 주었으며 $250^{\circ} \mathrm{C}$ 에서 $350^{\circ} \mathrm{C}$ 까지는 승온속도 $0.1^{\circ} \mathrm{C} / \mathrm{min}$ 로 가열하였고 $350^{\circ} \mathrm{C}$ 에서 $550^{\circ} \mathrm{C}$ 까지 승온속도 $0.5^{\circ} \mathrm{C} / \mathrm{min}$ 로 가열한 후, 800,900 , 그리고 $1000^{\circ} \mathrm{C}$ 까지 승온속 도 $2^{\circ} \mathrm{C} / \mathrm{min}$ 로 가열하여 각각의 온도에서 1 시간을 유지시켜 탄 소나노섬유 웹을 얻었다[27, 28]. Fig. 3에는 본 실험의 진행과 정을 모식도로 나타내었다.

\section{4. 분석}

$\mathrm{PAN} / \mathrm{DMF}$ 용액의 표면장력의 크기는 표면장력 측정기 (KRÜSS, Tensiometer K100)을 이용하여 고찰하였으며 측정 온도 $20^{\circ} \mathrm{C}$ 에서 각각 15 회 측정하여 평균값으로 나타내었다.

$\mathrm{PAN} / \mathrm{DMF}$ 나노섬유 웹의 형태학적 특성을 관찰하기 위해 주사전자 현미경(SEM; scanning electron microscope, JEOL Model 840A)을 사용하였고, 섬유의 직경크기는 $\mathrm{SEM}$ 으로 측 정된 사진에서 섬유를 100 개 무작위로 선정하여 분석하였다.

$\mathrm{PAN} / \mathrm{DMF}$ 나노섬유 웹의 전기적 특성은 체적저항측정기

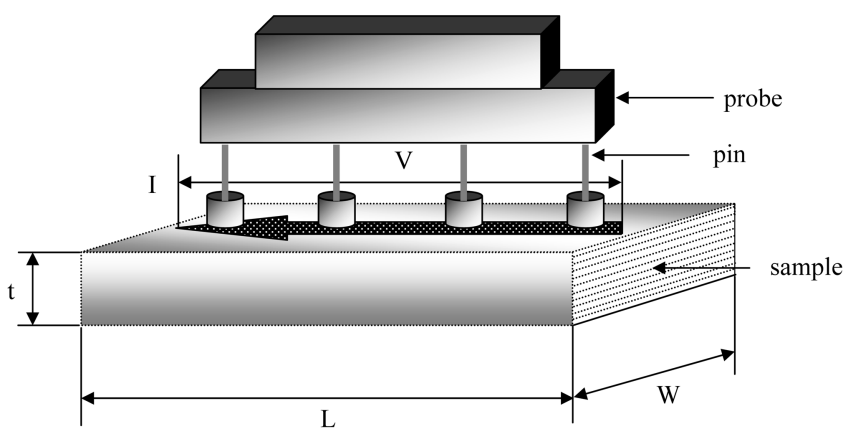

Fig. 4. Schematic diagram of volume resistivity measurement.

(MITSUBISHI Chemical Co., MCP-T610)를 사용하여 고찰하 였다. 체적비저항 값은 시편을 가로 $\times$ 세로 $\times$ 높이 $5 \times 20 \times 0.01$ $\mathrm{mm}^{3}$ 크기로 자른 다음 4탐침법을 이용하여 시편에 4 개의 핀 으로 된 전극을 직선상에 놓고 양 끝의 2 탐침 사이에 일정 전 류를 흘려서 안쪽의 2 탐침 사이에 발생하는 전위차를 측정하 여 구하였으며 Fig. 4에 체적저항 측정기의 모식도를 나타내 었다.

\section{3. 결과 및 고찰}

\section{1. 전기방사}

전기방사는 고분자 용액 또는 용융된 고분자 내에 고분자 사슬간의 정전기력을 발생시켜 같은 극으로 하전된 고분자 사 슬끼리 서로 반발력이 발생하고 임계전압 이상에서는 섬유상 으로 방사가 이루어진다고 알려져 있다 $[10,29]$.

고분자 용액의 표면 장력과 평행을 이룰 때의 임계전압은 다음 식 (1)과 같다[2, 30].

$$
V_{c}^{2}=4 \frac{H^{2}}{L^{2}}\left(\ln \frac{2 L}{R}-1.5\right)(0.117 \pi R \gamma)
$$

여기서, $V_{c}$ 는 임계전압, $\mathrm{L}$ 은 방사 변수인 capillary 길이, R은 capillary 반경, $\gamma$ 은 액체의 표면 장력 그리고 $\mathrm{H}$ 는 방사거리를 나타낸다.

또한, 고분자 용액의 표면 장력과 평행을 이룰 때의 최대 한 계전압은 다음 식(2)와 같다[2, 31].

$$
V=300 \sqrt{20 \pi r \gamma}
$$

여기서 $V$ 는 최대 한계전압, $r$ 은 낙하하는 액적의 반지름 그리 고 $\gamma$ 은 액체의 표면장력을 나타낸다.

식 (1), (2)는 단물질로 구성된 용액을 기준으로 제안된 식 으로, 최근 다양한 고분자 물질을 사용하여 전기방사를 실시 할 경우 실험적으로 임계전압을 산출하는 것으로 알려져 있다 [2]. Table 2는 PAN/DMF 용액의 표면장력의 크기와 식 (1), (2)를 이용하여 산출한 임계전압의 크기를 나타낸 것으로 10 
Table 2. Surface tension and applied voltage for PAN/DMF solution

\begin{tabular}{cccc}
\hline $\begin{array}{c}\text { Concentration } \\
(\text { wt.\%) }\end{array}$ & $\begin{array}{c}\text { Surface tension } \\
(\mathrm{N} / \mathrm{m})\end{array}$ & $\begin{array}{c}\text { Applied voltage } \\
(\mathrm{kV})\end{array}$ & $\begin{array}{c}\text { Max. applied } \\
\text { voltage }(\mathrm{kV})\end{array}$ \\
\hline 10 & 3.69 & 14.76 & 20.42 \\
\hline
\end{tabular}

wt.\%의 PAN/DMF용액의 표면장력의 크기는 $3.69 \mathrm{~N} / \mathrm{m}$ 로 방사 노즐의 끝부분에서 임계전압인 $14.76 \mathrm{kV}$ 에서 표면장력의 크기 와 정전기력이 서로 평형상태를 유지하다가 임계전압 이상에 서 섬유상의 방사가 이루어지며 최대 한계전압 $20.42 \mathrm{kV}$ 범위 까지 섬유상의 방사가 된다고 판단된다 $[30,31]$.

\section{2. 안정화 및 탄화 거동}

전기방사된 $\mathrm{PAN} / \mathrm{DMF}$ 나노섬유 웹을 고강도 나노섬유 웹 으로 만들기 위해서는 여러 공정을 거쳐야 한다. 제1단계는 고 온에서 섬유가 용융되는 것을 방지하기 위한 안정화 공정이고 제2단계는 탄소 이외의 나머지 원소들을 제거하기 위한 열처 리 공정인 탄화이며 제 3단계는 2단계에서 얻은 탄소섬유의 물성을 개선하기 위한 선택적 열처리 과정인 흑연화이다[32]

안정화 공정은 전기방사된 섬유 웹이 높은 온도에서 용융되 는 것을 막아 물리적인 특성이 우수한 섬유 웹을 제조할 수 있 는 공정으로 탄화수소가 도입된 산소에 의하여 축합이 일어나 는 공정이다. 전기방사된 섬유 웹의 우수한 물리적 성능을 발 현하기 위해서는 낮은 승온속도로 장시간 안정화 공정을 거쳐 야 한다[32]. 탄화공정은 불활성 분위기에서 $800 ~ 1200^{\circ} \mathrm{C}$ 의 온 도로 가열하면 $\mathrm{HCN}$ 기체가 많이 발생하고 $\mathrm{N}_{2}$ 기체의 증가도 현저히 일어나면서 $\mathrm{CH}_{4}, \mathrm{CO}_{2}, \mathrm{CO}$ 가 발생하고 섬유 내의 축 합고리의 구조가 늘어나고 불완전한 흑연 결정망면의 난층구 조가 생성되어 탄화함으로 고강도 섬유 웹이 만들어진다[32].

질소분위기 하에서 탄화시킨 섬유 웹의 탄화수율은 다음 식 (3)로 나타낸다[33].

$$
Y=\frac{S w-C w}{S w} \times 100
$$

여기서, $Y$ 는 탄화수율, $S w$ 는 안정화시킨 섬유의 질량백분율, $C w$ 는 탄소화시킨 섬유의 질량백분율을 나타낸다.

Fig. 5는 안정화 과정을 거친 전기방사 웹을 질소분위기하 에서 $800 \sim 1000^{\circ} \mathrm{C}$ 까지 탄화시킨 나노섬유 웹의 탄화수율을 나

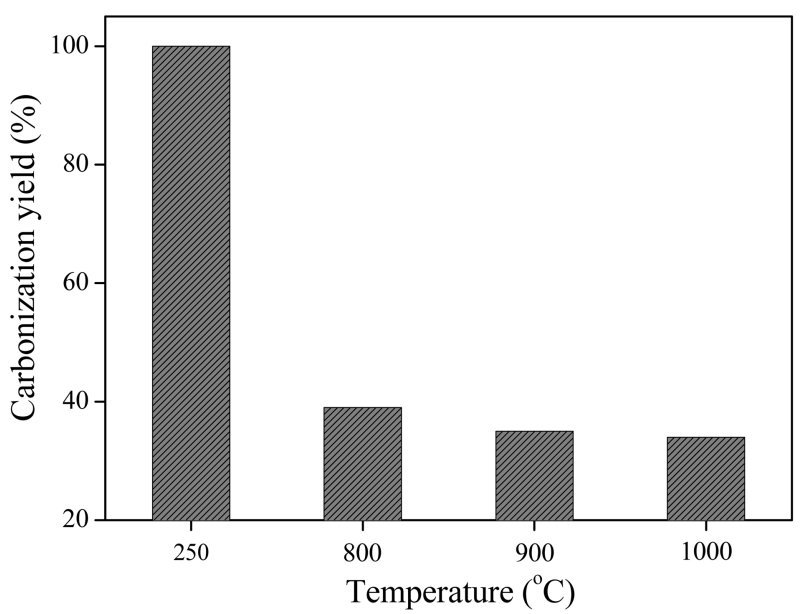

Fig. 5. Carbonization yield of PAN nanofiber webs.

타내었다. 탄화수율은 안정화 온도 $250^{\circ} \mathrm{C}$ 에서 탄화수율을 $100 \%$ 로 하였을 때 $800^{\circ} \mathrm{C}$ 에서는 $39 \%, 900^{\circ} \mathrm{C}$ 에서는 $35 \%$, 그 리고 $1000^{\circ} \mathrm{C}$ 에서는 $34 \%$ 의 탄화수율을 나타내었다. 이는 탄 화 과정시 온도증가에 따라 PAN/DMF 나노섬유 웹의 연소반 응이 활발하게 일어나고 PAN 섬유내의 비 탄소성분인 수소, 산소, 질소등 이종원소가 급격한 방출에 따른 중량감소의 결 과라 판단된다[33].

\section{3. 형태학적인 관찰}

Fig. 6은 방사거리 $10 \mathrm{~cm}$, 용액농도 $10 \mathrm{wt} \%$, 인가전압 15 $\mathrm{kV}$ 에서 전기 방사시킨 나노섬유 웹과 $250^{\circ} \mathrm{C}$ 에서 안정화시킨 나노섬유 웹, $800^{\circ} \mathrm{C}, 900^{\circ} \mathrm{C}, 1000^{\circ} \mathrm{C}$ 로 탄화시킨 나노섬유 웹 의 SEM 사진이며 각각의 섬유직경의 크기는 Fig. 7에 나타내 었다. 전기방사된 나노섬유 웹의 평균직경은 $605 \mathrm{~nm}$ 로 섬유 가 웹상으로 고루 분산되어 있는 분포형태로 엉김현상과 비드 를 가지지 않는 균일한 크기의 직경분포를 나타내었다. 안정 화시킨 나노섬유 웹의 평균 직경은 $513 \mathrm{~nm}$ 로 균일한 분포의 섬유를 얻을 수 있었다. $800^{\circ} \mathrm{C}, 900^{\circ} \mathrm{C}$, 그리고 $1000^{\circ} \mathrm{C}$ 에서 탄 화시킨 나노섬유 웹의 평균직경은 온도가 증가함에 따라 점점 작아져서 $310 \mathrm{~nm}, 182 \mathrm{~nm}$, 그리고 $160 \mathrm{~nm}$ 의 직경분포를 나 타내었고 섬유의 끊김현상도 부분적으로 관찰되었다. 이는 탄 화공정시 온도의 증가에 따른 섬유 웹의 활발한 연소반응과 $\mathrm{PAN}$ 섬유내의 이종원소의 방출이 급속히 진행되어 모폴로지

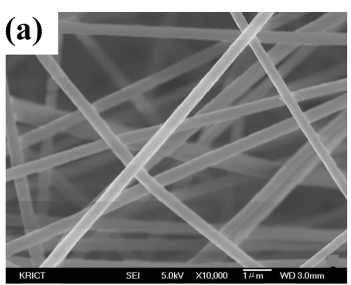

as spun

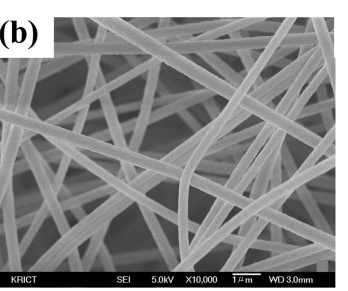

$250^{\circ} \mathrm{C}$

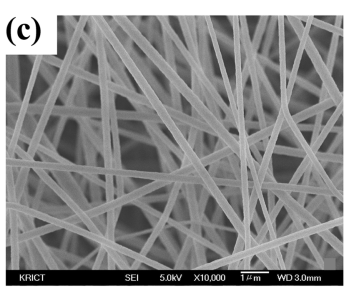

$800^{\circ} \mathrm{C}$

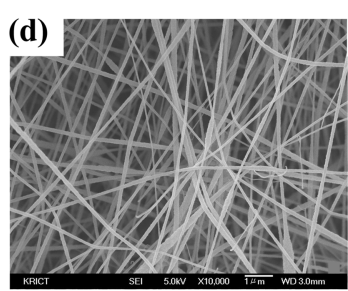

$900^{\circ} \mathrm{C}$

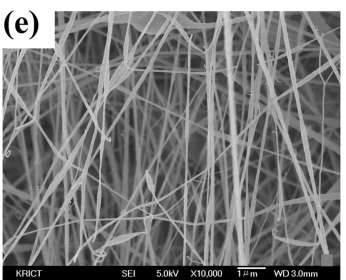

$1000^{\circ} \mathrm{C}$

Fig. 6. SEM microphotographs of PAN nanofiber webs: (a) as spun, (b) $250^{\circ} \mathrm{C}$, (c) $800^{\circ} \mathrm{C}$, (d) $900^{\circ} \mathrm{C}$, (e) $1000^{\circ} \mathrm{C}$. 


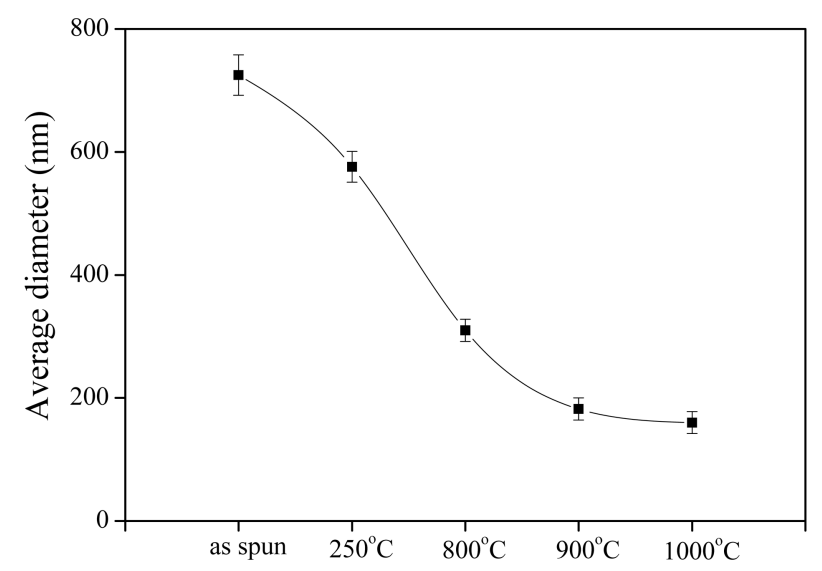

Fig. 7. Distance of average fiber diameter at stabilization and carbonization temperatures.

변화에 영향을 주었다고 판단된다.

\section{4. 전기적 특성}

일반적으로 재료의 전도성 판단기준으로 저항(Resistance)이 사용되고 있다. 이 저항을 단위체적당으로 표시한 값이 체적 저항률이다. 체적저항률은 재료분야에서는 체적 고유저항, 전 자분야에서는 비저항, 물리분야에서는 저항률 등으로 분야에 따라서 표현이 다르지만 재료의 고유 물리량으로 재료의 전도 성의 절대적인 척도로 사용되고 있다[34-36]. 이 값은 재료 고 유의 절대치이며 Fig. 4에 나타낸 것처럼 단면적에 일정 전류 를 흘려 떨어진 거리만큼 전극간의 전위차를 측정해서 구할 수 있다[37, 38].

$$
S=W \times t
$$

$R=V / I$

$P v=V / I \times W / L \times t$

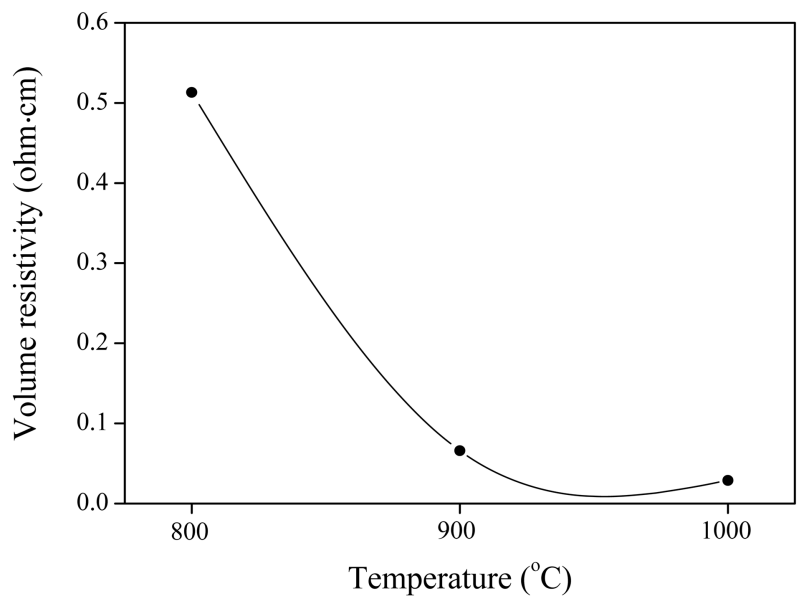

Fig. 8. Volume resistivity of PAN nanofiber webs at various carbonization temperatures.
여기서, $S$ 는 단면적, $W$ 는 시편의 폭, $t$ 는 높이, $R$ 은 저항, $V$ 는 전극간의 전위차, $I$ 는 전류, $P v$ 는 체적저항률, $L$ 은 거리를 나 타낸다.

Fig. 8은 탄소화 온도에 따른 PAN/DMF 나노섬유 웹의 체 적비저항을 나타낸 것이다. 탄소화 온도가 $800^{\circ} \mathrm{C}$ 에서 $1000^{\circ} \mathrm{C}$ 로 증가할수록 나노섬유 웹의 체적비저항 값은 $5.1 \times 10^{-1} \Omega \cdot \mathrm{cm}$ 에서 $3.0 \times 10^{-1} \Omega \cdot \mathrm{cm}$ 로 급격하게 감소하였다. 이러한 체적비저 항의 변화는 탄소화 온도가 증가함에 따라 고분자 특유의 비 결정구조가 탄소 결정구조로 변화하였으며 나노섬유 웹의 크 기가 감소하여 단위면적당 탄소화된 섬유의 개수가 증가하여 전기전도성이 향상되었다고 판단된다[32].

\section{4. 결 론}

본 연구에서는 탄소섬유 전구체인 PAN을 DMF에 용해시킨 후 전기방사를 이용하여 나노섬유 웹을 제조하였으며, 안정화 와 탄소화 과정을 거쳐 탄소섬유를 제조하여 직경, 모폴로지 및 전기전도적 특성에 대하여 고찰하였다. 그 결과, 탄화온도 가 $800^{\circ} \mathrm{C}$ 에서 $1000^{\circ} \mathrm{C}$ 로 증가함에 따라 평균직경이 $310 \mathrm{~nm}$ 에 서 $160 \mathrm{~nm}$ 로 감소하는 것을 관찰하였고 체적비저항 값은 0.513 $\Omega \cdot \mathrm{cm}$ 에서 $0.029 \Omega \cdot \mathrm{cm}$ 로 급속히 감소하는 것을 확인하였다. 따라서 본 실험을 통하여 탄화온도의 증가에 따라 PAN/DMF 탄소나노섬유 웹의 평균직경이 감소하는 것을 확인하였고 탄 화온도의 증가가 탄소나노섬유 웹의 전기전도적 특성에 상관 관계가 있는 것으로 판단되지만 구체적인 것은 향 후 보다 많 은 고찰을 통하여 검토할 예정이다.

\section{감사의 글}

이 논문은 과학기술부의 지원으로 수행하는 21 세기 프론티 어연구개발사업(수소에너지사업단)의 일환으로 수행되었음.

\section{참고문헌}

[1] Donnet, J. B.; Bansal, R. C. "Carbon Fibers", 2nd ed, Marcel Dekker, New York (1990).

[2] Buchko, C. J.; Chen, L. C.; Shen, Y.; Martin, D. C. Polymer 1999, 40, 7397.

[3] Shao, C.; Kim, H. Y.; Gong, J.; Ding, B.; Lee, D. R.; Park, S. J. Mater. Lett. 2003, 57, 1579.

[4] Kim, J. S.; Reneker, D. H. Polym. Eng. \& Sci. 1999, 39, 849.

[5] Reneker, D. H.; Chun, I. Nanotechnology 1996, 7, 216.

[6] Gibson, P.; Schreuder-Gibson, H.; Rivin, D. Colloids Surf. A: Physicochem. Eng. Asp. 2001, 187, 469.

[7] Ohgo, K.; Zhao, C.; Kobayshi, M.; Asakura, T. Polymer 
2003, 44, 841 .

[8] Deitzel, J. M.; Kleinmeyer, J. D.; Hirvonen, J. K.; Tan, N. C. B. Polymer 2001, 42, 8163.

[9] Kenawy, E. R.; Bowlin, G. L.; Mansfield, K.; Layman, J.; Simpson, D. G; Sanders, E. H.; Wnek, G. E. J. Control. Release 2002, 81, 57.

[10] Buchko, C. J.; Kozloff, K. M.; Martin, D. C. Biomaterials 2001, 22, 1289.

[11] Formhals, A. US Patent 1 1934, 975, 504.

[12] Reneker, D. H.; Yarine, A. L.; Fong, H.; Koombhongse, S. J. Appl. Phy. 2000, 909, 876.

[13] Oh, W. C.; Bae, J. S.; Ko, Y. S. Carbon Sci. 2006, 7, 105.

[14] Doshi, J.; Reneker, D. H. J. Electros. 1995, 35, 151.

[15] Shin, Y. M.; Hohman, M. M.; Rutledge, G. C. Appl. Phys. Lett. 2001, 78, 149.

[16] Fong, H.; Chun, I.; Reneker, D. H. Polymer 1999, 40, 4585.

[17] Deitzel, J. M.; Kosik, W.; McKnight, S. H.; Tan, N. C. B.; Desimone, J. M.; Crette, S. Polymer 2002, 43, 1025.

[18] Reneker, D. H.; Kataphinan, W.; Theron, A.; Zussman, E.; Yarin, A. L. Polymer 2002, 43, 6785.

[19] Taylor, G. I. Proc. Royal Soc. Lond. A 1964, 280, 383.

[20] Jaeger, R.; Bergshoef, M. M.; Battle, C. M. I.; Schönherr, H.; Vancso, G. J. Macromol. Symp. 1998, 127, 141.

[21] Park, S. J.; Lee, J. R. J. Mater. Sci. 1998, 33, 647.

[22] Park, S. J.; Kim, M. H.; Lee, J. R.; Choi, S. J. Colloid Interface Sci. 2000, 228, 287.

[23] Park, S. J.; Kim, B. J. Carbon Sci. 2005, 6, 257.
[24] Hajra, M. G.; Mehta, K.; Chase, G G Sep. Purif. Technol. 2002, 00, 1.

[25] Kang, Y. S.; Kim, H. Y.; Ryu, Y. J.; Lee, D. R.; Park, S. J. Polymer (Korea) 2002, 26, 360.

[26] Park, S. J.; Kim, K. D. Polymer (Korea) 1998, 22, 994.

[27] Park, S. J.; Seo, M. K.; Cho, M. S.; Lee, J. R. Polymer (Korea) 2000, 24, 237.

[28] Park, S. H.; Kim, C.; Jo, J. I.; Lee, W. J.; Yang, K. S. Appl. Chem. 2004, 8, 167.

[29] Warner, S. B.; Buer, A.; Ugbolue, S. C.; Rutledge, G. C.; Shin, M. Y. Project M98-D01, National Center Annual Reports, P. 83 (1998).

[30] Hendricks Jr, C. D.; Carson, R. S.; Hogan, J. J.; Schneider, J. M. AIAA J. 1964, 2, 733.

[31] Taylor, G. I. Proc. R. Soc. London A 1969, 313, 453.

[32] Park, S. J. “탄소재료”, 대영사 (2006).

[33] Kim, C.; Yang, K. S. Carbon Sci. 2002, 3, 210.

[34] Potschke, P.; Dudkim, S. M.; Alig, I. Polymer 2003, 44, 5023.

[35] Bin, Y.; Kitanaka, M.; Zhu, D.; Matsuo, M. Macromolecules 2003, 36, 6213.

[36] Stauffer, D. Introduction to the Percolation Theory, Francis and Taylor, (1991).

[37] Park, S. J.; Kim, H. C.; Kim, H. Y. J. Colloid Interface Sci. 2002, 255, 145.

[38] Seo, M. K.; Park, S. J. Chem. Phys. Lett. 2004, 395, 44. 